\title{
Prison Labour in Colonial India: A Case Study of Assam
}

Dimpy Das ${ }^{+*}$ and Dr Barnali Sarma*

\section{Abstract}

This paper examines the attitude of the British government towards the prisoners of Assam. Moreover, it investigates the policies adopted by the government about prison labour.

Prisons in Colonial India were known as the 'house of industries' rather than the house of rehabilitation and the disciplinary system that existed inside the prison walls emphasised more on attaining profit by instrumenting various types of punitive labour and rigorous methods of punishment. Throughout the Colonial period, the rules for prison administration was shaped and reshaped according to the needs of the colonial state and prisoners were squeezed in the name of discipline through prison labour. In India, the idea of reformation was boastfully propagated but never fully implemented inside the prisons. Prison and prison labour in colonial India has been discussed over a period of time in various academic platforms; however, no such discussions were made on the context of prisons of Assam. Therefore, through this study, an attempt has been made to offer an overview of the recommendations of the Prison Reform Committees and its implementation about prison labour and manufactures.

Keywords: Prison; Punitive Labour; Reformation; Punishment; Rehabilitation

\footnotetext{
${ }^{+}$Assistant Professor, Puthimari College, Puthimari Assam \& Research Scholar, Gauhati University,

${ }^{*}$ Corresponding Author Email: dimpy.das2011@gmail.com

¥ Associate Professor, Gauhati University, Department of History, Guwahati, Email: barnalisarma11@gauhati.ac.in (C) 2020 Das \& Sarma. This is an Open Access article distributed under the terms of the Creative Commons Attribution License (http://creativecommons.org/licenses/by/2.0), which permits unrestricted use, distribution, and reproduction in any medium, provided the original work is properly cited.
} 


\section{Introduction}

The prison was the final destination of the criminals if not sentenced to execution. According to the Prison Act 1894, the term 'Prison' means any jail or place used temporarily or permanently under the general or special orders of a Local Government for the detention of prisoners ("A memorandum dietaries of labouring prisoners in Indian jails", 1878-79). Punitive labour, also known as convict labour, is a form of forced labour used by the colonial government in India in order to mobilise scarce labour-power. The idea of reformation or deterrence circles around this form of labour as it largely contributed to the economy during the colonial period. In the words of Subhas Chandra Bose (Bose, 1940, p. 45). "in Colonial India, struggle against imperialism does not end with one's entry into jail, in fact, it is then that it enters upon its grimmest phase". All sense of modesty, justice and humanity was entirely unknown in the jails, and the prisoners were subjected to every form of humiliating and brutal treatment during the colonial period (Bose, 1940).

The study begins with a discussion of colonialism and its impact on the prisons and prisoners. It then reviews relevant literature underpinning this study. Following this, it critically discusses the findings by dividing it into three sectionsprisons in colonial Assam. Convict labour and manufacture industry in colonial Assam and contribution of prison industries of Assam to the economy.

\section{Colonialism and its Impact on Prison and Prison Labour}

Colonialism is one of the most important driving forces in the history of humankind. Practised since the ancient period of history, colonialism, as we know, has evolved since the Renaissance. After the discovery of sea routes and the development in maritime transportation, the process of establishing colonies received a boon (Phukan, 1998). Colonialism can be defined as the process of establishing political, economic and cultural hegemony over a weaker people or state by a powerful one (Kohn and Reddy, 2017). There was a debate following the Spanish invasion of America whether colonialism could be justified as a tool of civilising the countries outside Europe by preaching Christianity. In the 19th Century, the British political theorists defended the legitimacy of colonialism and justified the argument known as 'civilising mission'. However, the process and factors of colonialism concerning each former colony tend to differ. In the case of India, as Marx argued, it was the process of modernising a feudal society for which the British established political hegemony over India (Kohn \& Reddy, 2017).

British colonialism in India brought drastic transformation to every aspect of Indian society. The administration of law and the judiciary system of India was remodelled by the British. In pre-colonial India, the offenders were punished through harsh methods such as public execution, hanging, whipping, flogging, branding, or even starving to death. However, with the advent of British rule, imprisonment came to be recognised as the uniform mode of punishment (Nagda, 2016). Nevertheless, prisons in India under British rule were not only mere centres to reform the criminals, but the colonial authorities used the labour force of India to earn profit and prisons could provide them with an extensive labour force. Indeed, colonial prisons of the world, especially from the 19th Century, were operated to make a profit (Flynn, 1998). The prisoners were punished and held together regardless of their gender, age or crime (Flynn, 1998). The extensive use of convict labour in public works in the late 18th- and early $19^{\text {th }}$ Century India was not merely a way of keeping as many convicts as possible out of overcrowded jails, though that had its administrative attractions. It was a way of mobilising scarce labour-power, especially for road construction and repair. Prison labour and the labour market were inter-linked. Georg Rusche and Otto Kirchhmeimer (2017) analysed the prison labour in relation to labour market conditions. They argued that the supply and demand conditions of the labour market, as well as the condition of 
the public budgets, influence the type of penalties applied by the state. For example, in the case of an oversupply of labour, the main motive for prison labour will not be rehabilitation, but the disciplining of labour (Shah \& Scherrer, 2017). In Colonial India, however, the main motive of the prison labour was industrial profit, and therefore prisons were considered as the house of industry rather than the house of correction. The motive for reform was not humanity but economics, as Muncie also explains that the 'shift from corporal and capital punishment to systems of incarceration was done in order to socialise production and create a submissive and regulated workforce' (Muncie, 2001, p. 174).

During the 19th Century, almost all colonial authorities used prison labour as a means of producing output. For example, ex-convicts of England were exported to Australia to work as prison labour. There were fewer avenues for the convicts to work in prison. The convicts also did not rely upon prison labour to earn income. Once their sentence was over, they returned to their criminal activities. Indeed, Australia in the 19th Century became a hotspot of production. With new industries and a capitalist class emerging, there was a demand for labour. Prison labour fulfilled this demand. Evidently, William Wentworth, a large landowner and sheep farmer of New South Wales depended upon government-supplied convict labour to increase his production (Nicholas, 1990).

In Colonial India, using the convict as labour was a crucial part of the punishment system in the jails. However, like Africa and other colonies, prison labour in India was an integral part of the colonial economy. Only in Europe, prison labour was used as a tool of punishment and a method of rehabilitation. However, in colonial prisons, prison labour was used for both punishment and economic profit (Gibson, 2011). By the 1830s, cruel physical punishment was avoided and instead, the convict's physical strength was used as an instrument of earning profit through

\footnotetext{
1 The caste system was regarded as the basis of social order in India. It divided the Hindu Community into rigid hierarchical groups based on birth. Under this system a
}

convict labour (Arnold, 1994). The hierarchal social system of India was determined by caste ${ }^{1}$ since the pre-colonial period. The lower caste strata and their occupations were looked down upon by the higher caste people. The colonial authority utilised this social hierarchy inside the prisons, and caste became a factor which influenced labour and resistance (Arnold, 1994). As David Arnold (1994) in his article opined that "in 1796 it was considered that compelling highcaste convicts to work on the roads alongside 'common criminals' and sanitation works would be 'much more severe than a sentence of death"' (Arnold, 1994, p174). Therefore the Prison Reform Committee of 1836 recommended that the lower caste convicts with occupations like barbers, washermen and sweepers should perform their customary occupations in jail for the benefit of other prisoners and in the interests of prison economy (Arnold, 1994). This study examines the conditions of prison labour in Assam during colonial times. The following section discusses the existing literature relevant to the study.

\section{Survey of Literature}

Various works on prison labour such as Alex Lichtenstein's (1996), Twice the work of free labor have studied convict labour in the context of its transition from feudal to the capitalist mode of production. He further discussed the origin of convict leasing and its replacement by convict labour system. He gave examples of labours working on roads, public farms and other public enterprises and analysed the significance of convict labour. The present study, while considering this also attempts to study the colonial policies which were designed specially to establish a capitalist system in Indian jails. David Arnold (1994), in his article 'The Colonial Prison: Power, Knowledge and Penology in Nineteenth-Century India, claims that the colonial prison system in India worked as a way of mobilising scarce labour-power. Some prisoners, especially political prisoners, have also recorded their experiences and struggles in

person's birth determined his occupation. It was considered to be the steel frame of Hinduism (Desai, 2010, p. 227). 
jails through diaries and memoirs. However, it is difficult to trace the experiences of ordinary prisoners as the majority of them were illiterate, and they did not have their own records. However, a few of them recorded their experiences like Prabhat Chandra Sarma in Bilator Galpa aru Jailor Jibon (2018). Sarma described his own experience of being a political prisoner in the jail, and therefore he laid more emphasis on the tasks assigned to political prisons. He further provided a brief analysis of the outdoor labour system, which prevailed during the time of his imprisonment. The present study will probe how punitive labour acted as an active force in the establishment of manufacture industries.

Other vital studies on prison labour like Rabin Roychowdury's (2010) Black Days in Andaman and Nicobar Islands and Benudhar Kalita's (1994) Phulgurir Dhewa have discussed about transportation of convicts to the Andaman Islands. They analysed the brutal treatment of the prison authorities towards the political prisoners and mentioned a few instances of resistance by the prisoners. Furthermore, Phulugurir Dhewa discusses about the punishment system prevalent in the prisons. The book gives an insight into the discriminatory policies of the prison authority. However, the authors have given importance to political prisoners. The present study shall discuss the condition of ordinary prisoners as well as political prisoners in the context of prison labour and punishment system. Ashis Nandy (1983) in his work entitled The Intimate Enemy: Loss and Recovery of Self under Colonialism identifies colonialism as a process of dominating minds and bodies and also identifies remunerative labour through various systems of discipline as a tool of colonialism. The current study, while connecting the punitive labour with the colonial punishment system, also tends to offer an overall outlook of the Reports of various Jail Reform Committees and Conferences. Against these backdrops, this research describes the prisons of Assam and prisoners as economic labour.

\section{Discussion}

\section{Prisons in Colonial Assam}

The colonial authority classified the prisons of India into two categories- Central Prisons and District Prisons. The larger prisons were called central jails, and smaller entities were called district jails. In some regions, the district jails were also called Subsidiary jails. In Colonial Assam, there were three Central jails located at Guwahati, Sylhet and Jorhat. The district Jails were located at places like Tezpur, Dibrugarh, Silchar, Sibasagar, Karimganj, Tura, Hailakandi, Nowgong, Barpeta, Dhubri, Goalpara, Mangaldoi, North Lakhimpur, and Sadiya. There was one special woman Jail at Tezpur. In the district jails, the organisation was distinctly penal, and in Central Jails the organisation was generally industrial.

Further, the Jail Conference of 1913 believed that Subsidiary Jails, that is, lock-ups, where the prisoners were confined in order to serve their term of the sentence, should no longer be maintained as they are exceedingly expensive. Accordingly, the prisoners confined in those jails should be sent to the District Jails (Jail manufactures, 1914). It is to be noted that the prisoners of district jails were put to extramural labour. Therefore as suggested by the Conference, the colonial authorities planned on using the prisoners as labours by transferring them to district jails from subsidiary jails.

\section{Convict Labour and Manufacture Industry in Colonial Assam}

The colonial government looked for Punitive Labour or Convict Labour as a cheap and productive instrument of earning profit. The prisoners of Assam, like the prisoners of other parts of India, were used as convict labour by the colonial authority. In Assam, prisoners were employed on various types of works according to their capability. Those who were literate and seemed loyal were given the work of peon or lower rank jobs. The prisoners were awarded a small amount of money and also a reduction in their terms of sentence for rendering their service. The illiterate ones were employed as convict night warder. These warders also 
assisted the other night warders of the jail for better administration of the prison. The position above the night jail warders was of 'black pagadiwalas'. The black pagadiwalas were head of various departments like storerooms, carpenters, roof builders and so on (Sarma, 2018). This practice of using prisoners to run the administration of the jails was started in Malaya in the early part of the 19th Century, and soon it spread in Bengal and the rest of India. The aim of the system was to decrease the overall cost, but increasing administrative efficiency was not the concern of the authority (Arnold, 1994).

Sometimes the employment of convict as warders was highly questionable as they befouled the prison system with their own criminality ignoring their responsibilities. Therefore, the employment of convicts as warders was fiercely debated. As a result of the intense debate, the Government passed a scheme in 1923 aimed at training all the constables for a period of 6 months under Assam Rifles in order to improve the efficiency and the discipline of warder staff. Regardless of various kinds of training received by the jail warders, they were often seen misbehaving and humiliating the prisoners. Few incidents of Kakatanga Jail indicated the dominating and inhuman behaviour of the jail warders and authorities towards the prisoners. The prisoners were employed in the construction of a hospital for the jail. The convicts who were employed as hospital assistants were often drunk, and they abused the prisoners. There was no hospital inspection book which could reveal any remarks /orders made by Civil Surgeon. When the prisoners demanded it, they were severely punished by these hospital assistants (Notes on Jail matter, 1883)

In Assam, the prisoners were also employed in gangs beyond the jail precincts under the Public Works Department and under municipalities. The prisoners who were employed outside the prison were called 'Bahirsali Kaidis'. The Jail

\footnotetext{
2 The Meiji Restoration refers to the chain of events that resulted in the re-establishment of the imperial rule in Japan overthrowing the Tokugawa Shogunate in 1868. The Meiji Restoration restored the monarchical rule
}

Reform Committee of 1878 recommended for the abolishment of outdoor labour of prisoners and also for the construction of central prisons for better accommodation facilities of the prisoners in many parts of India. However, no such attention was paid to these recommendations as it involves heavy expenditure and no economic benefits or returns. The prisoners were made to work 9 hours per day. Bengal terms were adopted to define labour, namely penal, hard and light. Oil mills, wheat-grinding, stone-breaking, wood splitting were included under the penal head. Earthwork, road work, hoeing, garden work, husking paddy, brick-making, sewing, carpentry and weaving were included under hard labour. Similarly, bamboo, cane work and weeding were considered as light labour (Treatment of political prisoners, 1934).The employment of the prisoners also helped them to earn marks as mark system existed in the jails in order to discipline the prisoners strictly. Under the marking system, the convicts were awarded marks based on their behaviour, working ability and self-presentation. The marking system entitled the mark earner early release from his sentence period. The convicts of Assam were employed in jail industries such as weaving, oil pressing, bamboo and cane work, carpentry and smithy. Some prisoners were employed to work outside the prison in works like making and repairing the station roads, gathering and breaking stones and in repairing the jail buildings (Council resolution regarding discontinuance of oil pressing tasks in jails of Assam, 1931). The method of using convicts to work outside the prison was practised in Japan also. After the Meiji Restoration, ${ }^{2}$ the Japanese government opened up modern prisons. Western ideas influenced the Japanese authority to use the convicts to work in road construction, river dredging, mining coal and sulphur (Gibson, 2011).

under Emperor Meiji. Following the Meiji Restoration there was rapid industrialisation in Japan. Japan adopted western ideas and moved towards development (Vinacke, 2006, pp. 99-105). 


\section{Contribution of Prison Industries of Assam to the Economy}

The sole purpose of using convicts as labour was to attain a profit. Florence Bernault (2003) argues that economic motives were crucial to the prison project in many African colonies, where "prisoners provided a docile, cheap, and constantly available labour force for underpaid tasks" for private entrepreneurs and plantation owners as well as for the colonial administration (Bernault, 2003, p. 62). Oil pressing was a very profitable industry in Indian jails. In the jails of Assam, the Indian wooden type and the Alipore iron type of oil mills were used.

Before March 1904 oil-pressing was made a halfday task and convicts were expected to press five seers of mustard seed individually. In Assam, the Jail Manual Rules were not properly implemented by the jail authorities as in 1921 in Gauhati Jail, Major Hare, the Superintendent of the Gauhati Jail, instructed a task to the prisoners which was two times more than prescribed by the Jail Manual for the prisoners for the oil-pressing task. The chief commissioner of Assam found it dissatisfactory and dismissed the task immediately as it affected the health of the prisoners (Treatment of political prisoners in jail, 1921). In Dibrugarh Jail, during summer season two complete tasks on five seers scale were exacted from a healthy prisoner while in Tezpur Jail, 'B' class prisoners 3 were employed in oil-mills for a whole day, and they were required to press ten seers of seed per day. Whereas ' $A$ ' class prisoners were employed half a day and required to press five seers of seed and on the other half-day they were employed on other works (Report of the administration of the jail of the province of Assam, 1931).

In the Jails of Bihar and Orissa, the income derived in 1929 from this form of hard labour was INR 13, 587. In most of the Jails of India, the oil was consumed by the prisoners themselves. However, in the jails of Assam, the oil was not allowed to be consumed by the prisoners, and

\footnotetext{
${ }^{3}$ In the prisons of Assam political prisoners were divided into two categories: Class A and B prisoners, according to the condition of their health, education and mode of living before arrest. Class A prisoners were given better
}

the income derived from the Jails of Assam was much more than other parts of India. At Gauhati Jail alone during the year 1930, the income derived from the oil-pressing task was INR 787.33. The oil-pressing task was not only the form of remunerative hard labour in the jails of Assam, bamboo, cane and carpentry works were equally considered as hard labour (Bora, 1984). In 1931, the Prison Reform Committee recommended for the abolishment of the oilpressing task because it was found that the oil pressing task affected the prisoner's mind and health. However, the government of India ignored the recommendations and decided to continue the oil pressing task. The reason for this was that it became one of the most profitable industries in jail (Council resolution regarding discontinuance of oil pressing tasks in jails of Assam, 1931).

Jail manufacturers and industries had been carried out in many district prisons of Assam, and it also contributed a proportional amount to the cost of maintenance of prisons. (Hunter, 1879). For example, in the year 1881, the profit derived from manufactures was highest in the jails of Sylhet (INR46, 318), Gauhati (INR22, 078), Silchar (INR 10,335), Tezpur (INR10, 179), Dibrugarh (INR8, 255), Shillong (INR6, 260) and Sibasagar (INR 5, 088) in the province of Assam. (Jail manufactures, 1914)

In Colonial Assam, prisoners were employed in various extramural works and also in different works such as pottery-making, dhan-husking, brick-making, wheat-grinding, oil-pressing, cloth-weaving, tea garden labours and other similar tasks. The prisoners were also employed as wardens and prison servants. The bulk of the prison population were employed in altering, rebuilding and enlarging the central prisons at Gauhati and Sylhet under the supervision of the Public Works Department. The percentage of prisoners employed extramurally was large, and Municipalities made payment to the jail department at rates fixed by the Chief

treatment than the Class B prisoners in terms of food, letters, interviews and other facilities (Treatment of political prisoners in jail, 1921). 
Commissioner from time to time. The principal manufactures at Gauhati jail were oil-pressing, and cloth-weaving and the average profit derived was INR33 per head. At Tezpur Jail, oilpressing, gunny-weaving and rattan works were the principal manufactures and the average cash profit was INR26 per head. At Shillong Jail, bread-making and oil-pressing were the principal manufactures and average income derived from these manufactures was INR23 per head. At Mangaldai Jail, besides oil-pressing and Dhan-husking, paddy and mustard seed cultivation had been carried out with great success. The prisoners produced their own paddy and mustard seed for oil and their own vegetables. The total cash profit earned by the prisoners amounted to INR 855 per year (Jail manufactures, 1914).
The jail gardens also provided suitable occupation for the old, firm and convalescent convicts. Prisons were attached with a garden, and the vegetables grown in them were provided to the prisoners. In many jails, the surplus produce was sold to the public, and the amount derived was carried to the credit of the government. Besides the vegetable-gardens, there were two tea gardens attached to the jails of Cachar and Dibrugarh. At Cachar, 12 acres of land was under tea cultivation and produced about 15 maunds of tea every year. The garden at Dibrugarh was comparatively smaller, and only 4 acres of land was under tea cultivation and produced 3maunds of tea every year (Jail manufactures, 1914).

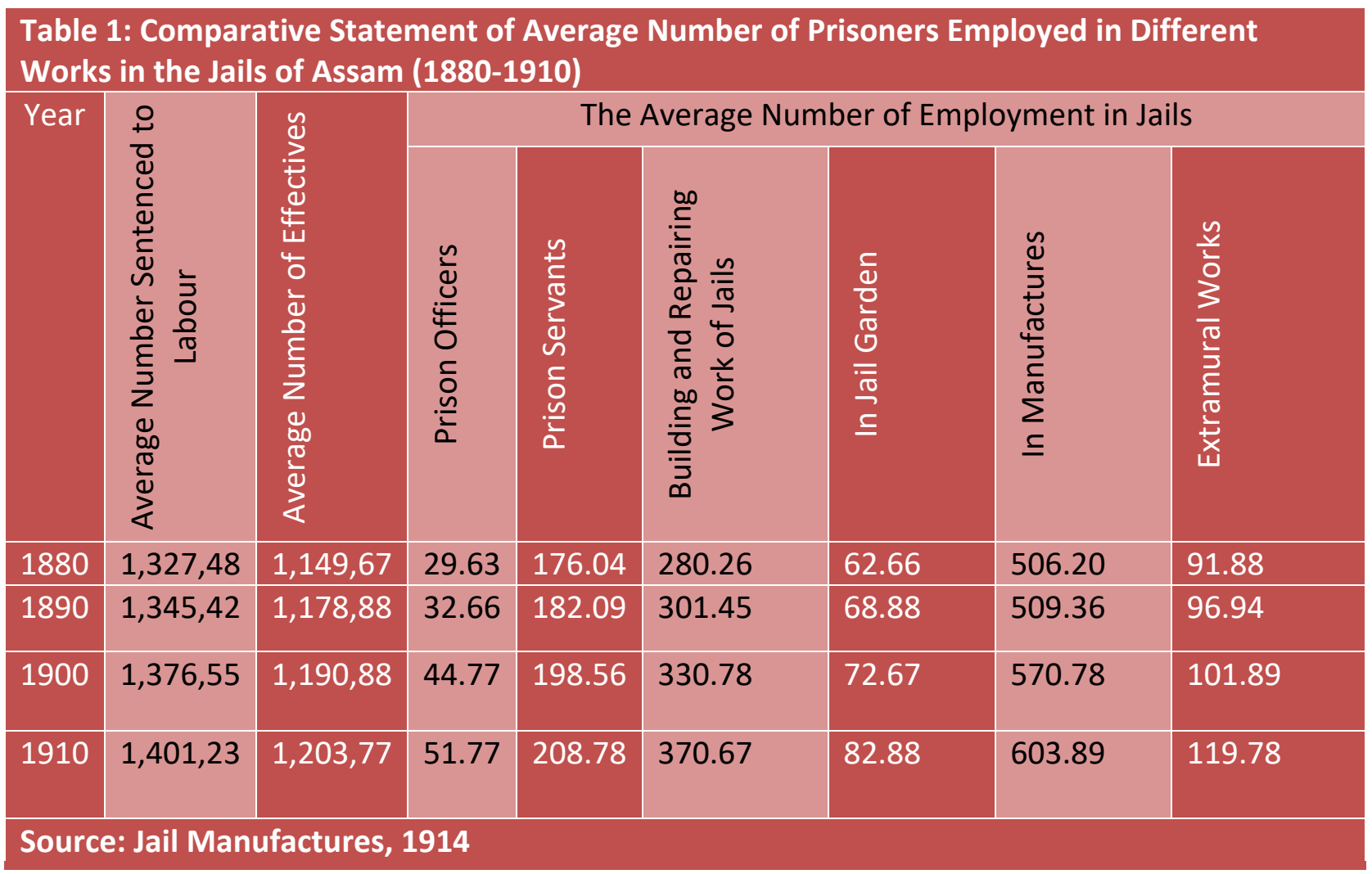

Table 1 displays the average number of prisoners sentenced to labour, the number of effectiveness, and the work in which they were employed during the years 1880, 1890, 1900, and 1910 . The average percentage of jail officers had been increased gradually due to difficulties faced by the jail authorities while guarding extramurally employed prisoners. The average percentage of jail servants also showed a gradual increase year by year because prisoners were forced to work as jail servants in their spare times. Maximum numbers of prisoners were employed in repairing the buildings of the central jails, and the Public Works Department supervised them. The table shows a constant increase in the number of average employment in jail gardens because the profit derived from these gardens was high. As it has been already 
discussed in the paper that there were many industries in the jails and therefore, the average number of employees in manufactures increased year by year. The average percentage of prisoners employed extramurally was primarily due to the scarcity of labour in Assam (Jail manufactures, 1914).

In Assam, most of the jail industries were in deplorable condition. The prison labours worked with old designed tools and implements. No efforts were made by the Government to introduce new designs which were up to date. The finishing of the products too was not satisfactory, and therefore the products though very durable and of good material failed to create a good impression on the customer. There were much scope and necessity of an allround improvement and the scheme for the improvement of the jail industries was drawn up by the Jail Reform Committee in 1919 (Jail Code, 1919-20). The suggestion of the Committee regarding the proper arrangement of existing industries was generally approved. The suggestion was mainly based on the standardisation of size and quality of the products. Later many articles which were made in the jails of Sylhet, Gauhati and Tezpur were sent to various departments of the Government (Das, 1983). Moreover, the quality of the manufactures used to decrease whenever the demand for the jail products was high. In the jails of Assam moonj ${ }^{4}$ mats were also manufactured specially in the jails of Jorhat and Tezpur. The manufacture of moonj mats heavily depended upon the supply of moonj grass which was supplied from the United Province. Handloom weaving was also considered as an important industry of Assam in the colonial period. It was also a part of the jail industry. However, the convict labours could not maintain uniform quality of the handloom products. Therefore the weaving industry of Assam had to suffer heavy losses. (Manufacturing of Moonj mats, 1934) The Prison Reform Committee in 1924 suggested that the weaving teachers of the jails should be sent for a refresher course to the Government

\footnotetext{
${ }^{4}$ Saccharummunja(a variety of grass found in river banks of India ).
}

Central Weaving Institute, Benares and one of the United Provinces Handloom Emporium Stores. However, the suggestion was not taken into consideration by the local Government as it involved a substantial expenditure (Inspection notes, 1930). Referring to convict labour in the prisons, Debeswar Sarma in his autobiography Herai Jowa Dinbor (1980) mentions that in all the lock-ups the under-trial prisoners were employed on extra-mural labour and they were put under the supervision of a special warder. In British colonies, forced labour was never legalised therefore convict labour both inside and outside proved significant to the colonial economy (Bernault, 2007).

\section{Conclusion}

The colonial rule in India aimed at earning profit in every possible way. The prison was therefore also used as an industry, and it was used as an institution for gaining more labour forces. Prisoners were treated as labours, and they were punished and held together regardless of their gender, age or crime. One aim of the colonial prison system was to make prisoner deterrent through hard labour and heavy punishment. The Prison Discipline Committees of 1838 and 1864 put forward the opinion that in order to make a prisoner disciplined, hard labour was the most robust tool. The Committees further forwarded various rules and regulations regarding punishment and also suggested many ways towards the reformation of prisoners. In the colonial prisons, there was systematic carelessness concerning the general needs and circumstances of the prisoners. The jail diet was terrible in every aspect, and it was not always given in the digestible form. An essential drawback of the administration system of Indian prisons during the colonial period was the absence of balance between authority and accountability. In the prisons, executive power is very necessary to maintain the balance. The primary notion of prison discipline during the colonial period was to confine a person and extract inhuman hard labour in the name of 
punishment and thereby to make imprisonment distasteful. The second notion of prison discipline was to cultivate work habits in prisoners so that after their release, they could rehabilitate themselves by these habits. Nevertheless, this notion was only for the namesake of the reformatory service as it was hardly brought into practice.

Like other provinces, in Assam too also prisoners were engaged in different works as labours and low-rank workers. In return, they were given nominal stipends or awarded with the reduction in their prison terms. The prisoners of Assam were engaged in industries like weaving, oil pressing, bamboo and cane work, carpentry and smithy. Some prisons sent prisoners to work outside the prison complex for works like road repairing, stone breaking etc. Credits were accorded to the prisoners based on their skill, and this helped them to get an early release. Oil pressing was a significant industry that thrived in the jails of Assam. The prisoners were engaged in pressing oil for 9 hours per day, and they were not even granted proper medical facilities. Sometimes, the rigorous attitude of the prison authority led to conflicts with the Provincial Government. Even in 1931, when the Prison Reform Committee recommended for the abolition of the oil pressing industry within the prisons, no steps were taken to implement it. The other known industries during the colonial prisons were blanket weaving, furniture industry, iron and leatherwork. In Indian Prisons convict labour both inside and outside proved significant as it contributed immensely in the growth of the colonial economy. Therefore the colonial government too tried every possible step to extract labour from the prisoners. This of course, was used at the stake of their health, and sometimes, even at the sake of their lives.

\section{References}

A Memorandum dietaries of labouring prisoners in Indian jails. (1878-79). Manuscript, Collected from Assam State Archives. Assam.

Arnold, D. (1994). The colonial prison: Power, knowledge and penology in nineteenth century India. In D. Arnold and D. Hardiman (Eds.), Subaltern studies VIII: Essays in honour of
Ranajit Guha (pp. 148-179). New Delhi, India: Oxford University Press.

Bernault, F. (2007). The shadow of rule: Colonial power and modern punishment in Africa. In I. Brown and F. Dikotter (Eds), Cultures of confinement: A history of the prison in Africa, Asia and Latin America (pp.55-94). New York, USA: Cornell University Press.

Bora, L. (1984). Mukti Jujar Sowaran (1st ed.). Guwahati: Publication Board of Assam.

Bose, S. (1940). The penal reform in India In Forward Bloc, 1 (30). 33-67.

Council resolution regarding discontinuance of oil pressing tasks in jails of Assam. (1931).

Manuscript, collected from Assam State Archives. Assam.

Das, A. K. (1983). Jivan-smriti (1st ed.). Guwahati: Publication Board of Assam.

Desai, A.R. (2010). Social background of Indian nationalism (6th ed.). Mumbai: Popular Prakashan Pvt. Ltd.

Flynn, N. (1998). Introduction to prisons and imprisonment (1st ed.). New York: Waterside Press.

Gibson, M. (2011). Global perspectives on the birth of the prison. In The American

historical review, 116(4), 1040-1063. doi: 10.1086/ahr.116.4.1040

Hunter, W. (1879). A statistical account of Assam (1st ed.). London: London Trubner \& Co. Inspection notes. HJ/45/1930. Manuscript, Collected from Assam State Archives. Assam.

Jail code J-82/1919-20 B-652-54. Manuscript, Collected from National Archives of India. New Delhi.

Jail manufactures HJL 88/ 1914. Manuscript, Collected from Assam State Archives. Assam.

Kalita, B. (1994). Phulgurir dhewa (1st ed.). Nagaon: Rubi Press.

Kohn, Margaret and Reddy, Kavita (2017). Colonialism in the Stanford encyclopaedia of philosophy Fall Edition. Retrieved from 
https://plato.stanford.edu/archives/fall2017/en tries/colonialism/

Lichtenstein, A. (1996). Twice the work of free labor (1st ed.). London: Verso.

Manufacturing of Moonj mats. GJL/156/1934. Manuscript, Collected from Assam State Archives. Assam.

Muncie, J. (2001). Prison histories: Reform, repression and rehabilitation, In E. McLaughlin and J. Muncie (eds) Controlling crime, (2nd ed.) (pp. 172-198). London, UK: Sage publications.

Nagda, P. (2016). A socio-legal study of prison system and its reforms in India (Ph.D).

Mohanlal Sukhadia University.

Nandy, A. (1983). The intimate enemy: Loss and recovery of self under colonialism (1st ed.) New Delhi: Oxford University Press.

Nicholas, S. (1990). Australia: An economical prison?. The economic history

review, 43(3), 470. doi: 10.2307/2596944

Notes on jail matter. H/J 34C/1883. Manuscript, Collected from Jorhat District Office.

Phukan, M. (1998). Rise of the modern West (1st ed.). New Delhi: Macmillan India.

Report of the administration of the jail of the province of Assam. (1931). Manuscript, Collected from Assam State Archives. Assam.
Roychowdury, R. (2004). Black days in Andaman and Nicobar Island (1st ed.). Delhi: Manas Publications.

Rusche, G., \& Kirchheimer, O. (2017).

Punishment and social structure (10th ed.).

Columbia: Columbia University Press.

Sarma, D. (1980). Herai jowa dinbor (1st ed.). Guwahati: Shree Guru Press.

Sarma, K. (1972). Krishna sarmar diary (1st ed.). Guwahati: Publication Board of Assam.

Sarma, P. (2018). Bilator galpa aru jailor jibon (1st ed.). Guwahati: Chandra Prakash Publication.

Shah, A., \& Scherrer, C. (2017). The political economy of prison labour: From penal welfarism to the penal state. Global labour journal, 8(1). doi: 10.15173/glj.v8i1.2774

Treatment of political prisoners. Aug 827/1934. Manuscript, Collected from West Bengal Archives. West Bengal.

Treatment of political prisoners in jail. (1921). Home/Confidential II (b). Manuscript, Collected from Assam State Archives. Assam.

Vinacke, H. (2006). A History of the Far-East in modern times (6th ed.). New Delhi: Surjeet Publications. 